\title{
WSPOMNIENIA NA 90-LECIE URODZIN PROF. ZW. DR HAB. FRANCISZKA GRONOWSKIEGO
}

\author{
Konrad Misztal \\ emerytowany prof. Uniwersytetu Gdańskiego, Gdańska Szkoła Wyższa
}

Jestem wielce zaszczycony, a zarazem szczęśliwy, że mogę wziąć udział w niecodziennej uroczystości uczczenia 90. rocznicy urodzin Profesora Franciszka Gronowskiego, którego darzę wielkim szacunkiem i przywiązaniem.

Miałem przyjemność wypowiedzieć swoje uczucia do Profesora z okazji jubileuszu 75-lecia Jego urodzin na łamach okolicznościowego wydawnictwa Uniwersytetu Szczecińskiego - Trzymajmy się morza w 2002 roku, no ale obecny jubileusz jest wyjątkowy i niezwykły.

Do Profesora Gronowskiego absolutnie nie pasuje określenie „sędziwy jubilat”, gdyż jest wciąż młody duchem, ale myślę, że sformułowanie „dostojny jubilat” jest jak najbardziej adekwatne do tych nadzwyczajnych okoliczności.

Nie będę się wypowiadał na temat osiągnięć naukowych, dydaktycznych i organizacyjnych Profesora, gdyż reprezentujemy dwie odrębne dyscypliny naukowe, a poza tym nie wypada, by młodszy kolega oceniał mistrza i mentora, od którego wiele się nauczył. Skoncentruję się zatem na naszych wieloletnich i wielorakich kontaktach naukowych i przyjacielskich.

Tak się szczęśliwie dla mnie złożyło, że Profesor Gronowski był często obecny w moim życiu naukowym, że miałem okazję być z Nim w bliskich kontaktach naukowych, a także, że mogłem czerpać z Jego mądrej filozofii życiowej. Tak już jest, że młody adept nauki, wchodzący dopiero w środowisko naukowe i stawiający pierwsze kroki w nauce, uczy się od osób o ugruntowanej pozycji naukowej właściwie wszystkiego, co składa się na pracę naukowo-wychowawczą i dydaktyczną. Tak też było i w moim przypadku. Obserwowałem i słuchałem moich starszych kolegów, a zwłaszcza tych o niezaprzeczalnej osobowości naukowej i silnej postawie moralnej, emanujących z całą wyrazistością na najbliższe otocznie, będących autorytetem i wzorem do naśladowania.

Do pierwszych, jeszcze zbyt oficjalnych, kontaktów naukowych i osobistych z Profesorem Gronowskim doszło w latach siedemdziesiątych na jednym z odbywających się cyklicznie, co dwa lata, spotkań pracowników naukowo-dydaktycznych polskich uczelni kształcących ekonomistów transportu. Były to spotkania bardzo potrzebne i pożyteczne $\mathrm{z}$ dwóch podstawowych powodów. Po pierwsze stanowiły one forum wymiany poglądów i doświadczeń w zakresie ekonomicznej problematyki transportowej i okołotransportowej, będącej przedmiotem badań naukowych i dydaktyki polskich ośrodków akademickich. Po wtóre, spotkania te znakomicie umożliwiały integrację polskiego środowiska myśli ekonomicznej w dziedzinie trans- 
portu, poprzez wzajemną wymianę poglądów - doświadczeń (zwłaszcza dydaktycznych), bliższe osobiste poznanie się, a często i zadzierzgnięcie przyjaźni. Niestety w późniejszych latach, ta ze wszech miar wskazana praktyka, została całkowicie zaniechana i niezastąpiona żadnym innym rozwiązaniem.

Z Profesorem Gronowskim wielokrotnie spotykałem się na różnych konferencjach, zjazdach i sympozjach naukowych. Profesor bywał też częstym gościem mojej macierzystej uczelni jako recenzent prac doktorskich i habilitacyjnych, co stwarzało okazje do spotkań i rozmów. Również ja, już jako samodzielny pracownik naukowy, zadebiutowałem jako recenzent pracy doktorskiej właśnie na Wydziale Ekonomiczno-Inżynieryjnym Politechniki Szczecińskiej, macierzystym Wydziale Profesora.

Moja bliższa współpraca naukowa z Profesorem F. Gronowskim przypadła na lata 19761980, w ramach badań nad problemem resortowym ówczesnego Ministerstwa Nauki, Szkolnictwa Wyższego i Techniki, dotyczącym roli transportu morskiego w gospodarce narodowej PRL. Organizację i koordynację tych badań ministerstwo powierzyło Instytutowi Ekonomiki Transportu Morskiego Uniwersytetu Gdańskiego. Koordynatorem badań został mianowany prof. zw. dr hab. Tadeusz Łodykowski, dyrektor wspomnianego Instytutu, natomiast mnie przypadła funkcja sekretarza naukowego problemu, jako zastępcy dyrektora do spraw naukowo-badawczych. W realizacji badań uczestniczyło szerokie grono akademickich naukowców, reprezentujących środowisko transportu morskiego w Polsce oraz liczni przedstawiciele praktyki gospodarczej. Profesor Franciszek Gronowski został koordynatorem badań, w IV grupie tematycznej - Wpływ żeglugi morskiej i portów morskich na bilans płatniczy kraju. W ramach tej grupy kierował także pracami nad tematem Wpływ żeglugi morskiej na bilans płatniczy kraju. $\mathrm{Z}$ racji pełnionej przeze mnie funkcji miałem bezpośredni kontakt ze wszystkimi kierownikami grup tematycznych i tematów. Wówczas to nawiązała się moja ścisła i bezpośrednia współpraca naukowa z Profesorem Franciszkiem Gronowskim, która w następnych latach pogłębiała się na różnych płaszczyznach życia akademickiego.

W 1985 roku Profesor Franciszek Gronowski został powołany przez Radę Wydziału Ekonomiki Transportu Uniwersytetu Gdańskiego na recenzenta mojego dorobku naukowo-dydaktyczno-organizacyjnego w związku z wszczęciem postępowania o nadanie mi tytułu naukowego profesora. Oprócz wysoce pozytywnej oceny merytorycznej mojego dorobku, Profesor w ciepłych słowach scharakteryzował moją sylwetkę jako pracownika akademickiego i po prostu człowieka, co w tego typu recenzjach na ogół się nie zdarza. Nie była to zatem szablonowa, niejako urzędowa recenzja, lecz zawierająca także stosunek osobisty recenzenta do ocenianego. Ten miły dla mnie akcent recenzji utkwił mi głęboko w pamięci.

Następny mój awans naukowy związany jest także z Profesorem Gronowskim. Otóż, gdy w 1994 roku wszczęto na Wydziale Ekonomiki Transportu Uniwersytetu Gdańskiego postępowanie w sprawie powołania mnie na stanowisko profesora zwyczajnego, na jednego z recenzentów wyznaczono Profesora Gronowskiego - mogę zatem stwierdzić, że Profesor jest współtwórcą mojej kariery naukowej.

Kolejna płaszczyzna moich kontaktów naukowych z Profesorem dotyczyła współpracy w zakresie rozwoju młodej kadry naukowej. W 1979 roku Rada Wydziału Ekonomiczno-Inżynieryjnego Politechniki Szczecińskiej poprosiła mnie o ocenę pracy doktorskiej, której promotorem był doc. dr hab. Krzysztof Luks. Recenzentem tej pracy był także Profesor Gronowski, 
który z kolei recenzował rozprawę doktorską napisaną pod moim kierunkiem na Uniwersytecie Gdańskiem w 1994 roku.

Wspomnę również o naszych spotkaniach na Sejmikach Morskich organizowanych przez Ośrodek Myśli Morskiej Katolickiego Stowarzyszenia „Civitas Christana” w Szczecinie. To właśnie Profesorowi Gronowskiemu zawdzięczam włączenie mnie w działalność sejmików morskich, na których występowałem z referatami i publikowałem swoje opracowania w ich wydawnictwach.

Aby w pełni uwypuklić moje związki naukowe z Profesorem Gronowskim, pragnę również zaznaczyć, że Profesor recenzował podręcznik akademicki Organizacja i eksploatacja portów morskich, opracowanego przeze mnie przy współudziale Stanisława Szwankowskiego, wydanego w 1999 roku. Jak zwykle recenzja Profesora była rzeczowa i konstruktywna, umożliwiająca udoskonalenie treści podręcznika.

Profesor recenzował również moje artykuły, które publikowane były w Zeszytach Naukowych Wyższej Szkoły Morskiej w Szczecinie. Moje kontakty naukowe z Wyższą Szkołą Morską w Szczecinie zawdzięczam także Profesorowi, który wprowadził mnie w to środowisko naukowe. Dzięki Profesorowi wystąpiłem w tej uczelni z cyklem wykładów na temat zewnętrznych i wewnętrznych uwarunkowań funkcjonowania i rozwoju polskich portów morskich oraz wygłosiłem referat na konferencji zorganizowanej przez Instytut Eksploatacji Portów i Floty w 1995 roku.

Na zakończenie moich wspomnień chciałbym jeszcze jedno podkreślić, a mianowicie recenzje Profesora Gronowskiego stały się dla mnie wzorem do naśladowania. Na ogół przyjmuje się, że recenzja powinna być krytyczna, czyli wytykająca głównie błędy i usterki, często bez wskazania sposobu ich poprawy, natomiast zazwyczaj unika się w niej pozytywów, pochwał. Recenzje pisane przez Profesora Gronowskiego były natomiast konkretne i konstruktywne, życzliwe a nie szkodzące, wspomagające a nie przygnębiające autora, doradzające, lecz nie mentorskie. Tak postępuje mistrz, który wskazuje właściwą drogę uczniowi, to jest jego powinność i powołanie.

Obydwaj jesteśmy obecnie na emeryturze. Pozostały nam jedynie wspomnienia, refleksje i kontakty telefoniczne, których tematem jest głównie stan zdrowia i samopoczucia.

Bardzo sobie cenię, że Profesor zalicza mnie do grona swoich przyjaciół.

Z okazji pięknego Jubileuszu życzę Dostojnemu Jubilatowi długich lat życia w zdrowiu i spokoju. Niech dobre samopoczucie nigdy Go nie opuszcza, a dobrą radą niech wspiera następne pokolenia. 